\title{
COLETTE VAN GOCH CONTROLLER ONDER WATER
}

\author{
Naam: Colette van Goch \\ Leeftijd: 48 \\ Burgerlijke staat: gehuwd \\ Opleiding: arbeids- en organisatie \\ sociologie, heao bedrijfseconomie \\ Functie en werkgever: business \\ controller bij SEIN IStichting \\ Epilepsie Instellingen Nederland) \\ Lid van Fizi sinds: maart 2014
}

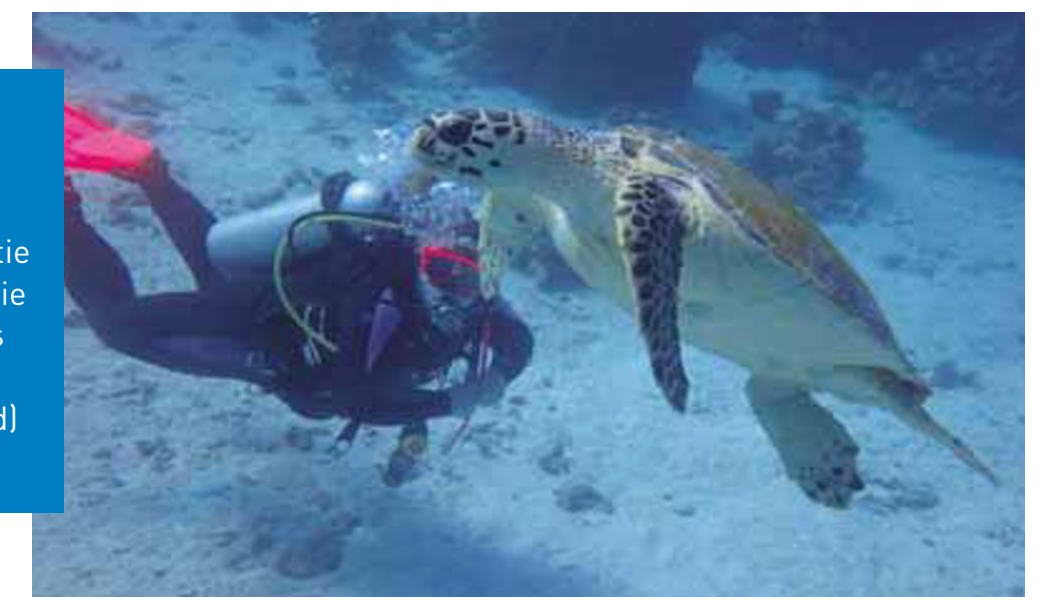

Het prachtige onderwaterleven (zowel in de tropen als ook in Nederland) is elke keer weer fascinerend. Ruim $70 \%$ van het oppervlakte van onze aardbol is zee, daar is zoveel moois te zien. Duiken is, als je eenmaal onderwater bent, zeer ontspannend. Oké, je loopt eerst met minstens 25 kilo uitrustig op je rug te sjouwen, maar onderwater merk je dat niet meer en kom ik echt tot rust. Hoe langer je duikt hoe meer je je grenzen verlegt door meer uitdagende duiken te maken en vervolgopleidingen te volgen. Je moet dan met name denken aan moeilijker duikomstandigheden zoals diepte, stroming, zicht maar ook bijvoorbeeld duiken in wrakken of grotten enzovoort.

Het hele gezin houdt van duiken, ook onze ondernemende en sportieve kinderen. Vooral als het gaat om duiken in de Rode Zee, waar je regelmatig dolfijnen of schildpadden et cetera tegenkomt. Het komt niet zo vaak voor dat een heel gezin duikt, dus toen onze jongste zoon nog maar net dook kwam hij na een duik als ukkie tussen allemaal grote mannen uit het water. Hierop zei iemand op de kant : 'oh, het water is blijkbaar vandaag erg warm, die duiker is helemaal gekrompen'.

Als duikinstructeur kan ik mensen begeleiden bij een introductieduik in het zwembad of een volledige duikopleiding geven en train ik ook gelijk mijn eigen duikvaardigheden. Wat erg leuk is aan het duiken met beginnende duikers is dat zij dingen zien die mij al niet meer opvallen omdat het zo gewoon is. Hun enthousiasme werkt aanstekelijk. Maar als instructeur zie ik ook dingen waar de cursisten niet over nadenken, zoals veiligheidsaspecten en risico's. Je wilt graag dat ze een leuke duik ervaren, maar ook dat ze weer veilig boven komen.
Ik heb al menig collega enthousiast gekregen om een introductieduik te maken en twee collega's hebben zelfs de gehele duikopleiding gedaan.

In mijn werk als business controller ben ik adviseur en sparringpartner, met mijn adviezen maken onze managers hun eigen keuzes. Als duikinstructeur heb ik een soortgelijke rol. Ik adviseer en begeleid duikers in opleiding met als einddoel dat ze zelfstandige duikers worden die zonder begeleiding veilig met hun eigen buddy kunnen duiken. Vaak krijg ik vragen als 'is duiken niet gevaarlijk'? Dat is het niet, maar je moet wel goed weten waar je mee bezig bent en duiken binnen de gestelde veiligheidsnormen. Ook checken we voorafgaand aan elke duik onze complete duikuitrusting en stellen we een duikplan op waarin we risico's benoemen. Net als bij het duiken is ook risicomanagement aandachtsgebied in mijn werk. Didactische en sociale en communicatieve vaardigheden zijn belangrijk bij zowel mijn vak als mijn hobby. Of ik nu een les geef voor het duiken of een presentatie aan ons management over de kwartaalcijfers, in beide situaties moet ik mensen meenemen en bepaalde kennis overdragen. Ook analytische vaardigheden komen bij beide van pas. Dat je als controller handig moet zijn met cijfers is bij iedereen wel bekend. Maar ook bij het duiken maken we berekeningen, zodat we voor een duik weten of we wel genoeg lucht bij ons hebben om de geplande duik te kunnen maken.

In elke situatie moet je proberen rustig te blijven en handelen volgens SADD in geval van een calamiteit: Stop, Adem, Denk na, Doe. Ook bruikbaar voor op het werk. 